\title{
INVESTIGATION PROPERTIES OF HIGH FREQUENCY WELDED STEEL PIPES FOR NATURAL GAS TRANSPORTATION MADE OF X60 STEEL
}

\section{ISTRAŽIVANJE OSOBINA VISOKOFREKVENTNO ZAVARENIH CEVI OD ČELIKA X60 ZA TRANSPORT PRIRODNOG GASA}

\author{
Originalni naučni rad / Original scientific paper \\ UDK / UDC: 621.791:621.643
}

\section{Rad primljen / Paper received:}

Jun 2017.

Ključne reči: visoka frekvenca, zavarivanje, kontaktori, čelik x60, mikrostruktura

\section{ABSTRACT}

Basic idea in this research work is to check prescribed quality requirement of steel pipes welded by implementation of high frequency contact welding process (HFCW). These pipes are intended for natural gas transportation. As a raw material for pipes production was used $\mathrm{X} 60 \mathrm{M}$ steel coils with thickness of $6.5 \mathrm{~mm}$. Outer diameter of pipe is $\Phi 508$ and length $12000 \mathrm{~mm}$. Preliminary welding procedure is given based on personal experience and technical knowledge. Special attention was paid to the most important welding parameters: current frequency, voltage and welding speed. After performing of welding additional heat treatment (normalization) of the welded pipes (joints) was performed at the temperature of $900^{\circ} \mathrm{C}$.

In order to confirm proposed welding technology, complex investigations were performed. As first chemical analysis of base metal was performed. Nondestructive testing encompass visual inspection, and ultrasound testing of pipes, while destructive testing consists of tensile testing, bend testing and hardness measurement. Besides, for analysis of micro and macro structure of welded joint metallographic investigation was made. Hydrostatic test and flattening test as technological investigations were performed too. Carried investigations confirmed that produced pipes with predicted welding parameters completely fulfilled standard requirement, and serial production of ordered pipes for natural gas transportation was realized.
Adresa autora / Author's address:

Faculty of Technology and Metallurgy - Ss Cyril and Methodius University Skopje, Republic of Macedonia ${ }^{1}$

sveto@tmf.ukim.edu.mk

Key words: high frequency, welding, contactors, x60steel, pipes, microstructure

\section{REZIME}

Osnovna ideja u ovom istraživačkom radu je provera predviđenih zahteva kvaliteta čeličnih cevi zavarenih primenom postupka kontaktnog visokofrekventnog zavarivanja (HFCW)). Ove cevi su namenjene za transport prirodnog gasa. Kao sirovina za proizvodnju cevi korišćene su trake od čelika X60M debljine $6,5 \mathrm{~mm}$. Spoljašnji prečnik cevi je $\$ 508$ a dužina 12000 mm. Preliminarni postupak zavarivanja je odabran na osnovu ličnog iskustva i tehničkog znanja. Posebna pažnja je posvećena najvažnijim parametrima zavarivanja: frekvencija struje, napon i brzina zavarivanja. Nakon zavarivanja, sprovedena je dodatna termička obrada (normalizacija) zavarenih cevi (spojeva) na temperaturi od $900^{\circ} \mathrm{C}$.

$\cup$ cilju potvrđivanja predložene tehnologije zavarivanja, preduzeta su kompleksna istraživanja. Kao prvo, urađena je hemijska analiza osnovnog materijala. Ispitivanje bez razaranja obuhvata vizuelni pregled i ultrazvučno ispitivanje cevi, dok se ispitivanje sa razaranjem sastoji od ispitivanja zatezanjem, savijanejm i merenja tvrdoće. Osim toga, za analizu je sprovedeno mikro i makro strukturno ispitivanje. Hidrostatičko ispitivanje i provera spljoštavanjem su takođe obavljena kao tehnološka istraživanja. Sprovedeno istraživanje je potvrdilo da su proizvedene cevi, predviđenim parametrima zavarivanja u potpunosti ispunjeni zahtevi standarda, a serijska proizvodnja naručenih cevi za transport prirodnog gasa je ostvarena. 


\section{Introduction}

Over the past few decades severe demands were placed on the pipes manufacturer with respect to the development and processing of material for pipeline. Generally longitudinally welded steel pipes are used for gas and oil transportation because of high safety and economical solution. Welded pipes must possess high strength and toughness, because of high pressure of the a fluid inside the pipelines and outer pressure of the soil to the grounded pipelines [1].

More than eight million stons of steel pipes are produced in the world every year. Most of them are produced from standard steel grades. Bigger challenge for pipe producers is manufacturing of pipe from $X 60$, and production of $X 70$ and $X 80$ need special efforts and measures $[2,3]$. High frequency tube welding is one of the most forgiving industrial processes nowadays and it is possible to produce acceptable tubing for most purposes. High frequency welding is a form of electrical resistance welding (ERW). A voltage is applied (HF contact) or induced (HF induction) across the edges of the open tube just prior to the point of closure. This voltage causes a current to flow along the edges to the point where they meet, causing rapid heating of the metal. Pressure is applied by the welding rolls, which forces the heated metal into contact, forming a hot diffusion bond. This pressure forces molten metal and any impurities out of the weldment [4]. The only real difference between high frequency contact and induction welding is that with contact welding, the voltage is applied directly to the strip edgesby means of sliding contacts, whereas in the case of induction welding, the voltage is induced by the magnetic flux surrounding the coil. The reason for using a higher frequency is that in the case of induction welding, it is desirable to keep the size of the coil reasonably small. The higher the frequency, the less flux is required. The higher frequencies also affect the behavior of the current that flows in the "vee" wedge. As frequency is increased, the current tends to concentrate closer and closer to the edges of the strip. This is partly due to the "skin effect" which causes current to flow on the surface of conductors at high frequency, and partly due to the "proximity effect" which causes current on adjacent conductors to concentrate on the adjacent surfaces. Both of these effects are caused by distortion or interaction between the magnetic fields associated with the current flow $[5,6]$. Frequencies used for tube welding are in the range between roughly $100 \mathrm{kHz}$ to $800 \mathrm{kHz}$, with lower frequencies being used for large, heavy wall tube, and the upperrange

\section{Uvod}

$U$ proteklih nekoliko decenija, pred proizvođače cevi postavljeni su oštri zahtevi vezani za razvoj i izradu materijala za cevovode.Uglavnom se za transport nafte i gasa koriste uzdužno zavarene čelične cevi zbog visoke sigurnosti i kao ekonomično rešenje. Zavarene cevi moraju imati visoke vrednosti čvrstoće i žilavosti, zbog visokog pritiska fluida unutar cevovoda i spoljašnjeg pritiska tla na ukopane cevovode [1].

Više od osam miliona tona čeličnih cevi godišnje se proizvede u svetu. Većina se proizvodi od standardnog čelika. Veći izazov za proizvođače cevi je proizvodnja cevi od X60, a proizvodnja X70 i X80 zahteva posebne napore i mere $[2,3]$.

Visokofrekventno zavarivanje cevi je jedan od najvažnijih industrijskih procesa danas, tako da je moguće proizvesti prihvatljive cevi za većinu namena. Visoko frekvenventno zavarivanje je oblik elektrootporskog zavarivanja (ERW). Napon se ostvaruje (HF kontaktom) ili indukovanjem (HF indukcija) preko ivica otvora cevi samo do mesta zatvaranja. Ovaj napon uzrokuje da struja prolazi duž ivice do tačke gde se susreću, što uzrokuje brzo zagrevanje metala. Pritisak se postiže valjcima za zavarivanje, koji guraju zagrejani metal u kontakt, formirajući vrući difuzioni sloj. Ove sile pritiska rastopljenog metala izbacuju sve nečistoće iz zavarenog elementa [4].

Jedina prava razlika između visokofrekvetnog zavarivanja kontaktom i indukcijom je da se kod kontaktnog zavarivanja, napon ostvaruje direktno na ivicama trake pomoću kliznih kontakata, dok u slučaju indukcijskog zavarivanja, napon se indukuje magnetnim fluksom koji okružuje zavojnicu. Razlog za korišćenje većih frekvenci je, da je u slučaju indukcijskog zavarivanja, poželjno zadržati veličinu zavojnica razumno malom. Što je veća frekvenca, potreban je manji fluks.

Veće frekvence takođe utiču na ponašanje struje koja teče u "V" klin. Kako se povećava frekvenca, struja teži da se koncentriše sve bliže i bliže ivicama trake. To je delom zbog "skin efekta", koji uzrokuje da struja prolazi po površini provodnika pri visokim frekvencama, a delom zbog "efekta blizine" koji izaziva struju na susednom provodniku da se koncentriše na susednim površinama. Oba ova efekti su uzrokovana izobličenjem ili interakcijom između magnetnih polja usled protoka struje [5,6]. otvorene cevi. Frekvence koje se koriste za zavarivanje cevi su u rasponu od otprilike $100 \mathrm{kHz}$ do $800 \mathrm{kHz}$, niže frekvence se koriste za velike, tankozidne cevi, a gornji opseg koji se koristi za male, tankozidne proizvode, posebno od obojenih 
being used for small, thin walled products, especially those using nonferrous material. The current that flows along the edges of the strip to the apex of the "vee" wedge the strip to welding temperature. Current will also tend to flow around the inside circumference of the open tube. This heats the entire tube, and does not contribute to the welding process.

Thermo-mechanical control process (TMCP) is one of microstructural control techniques, combining controlled rolling and controlled cooling, to obtain excellent properties of steel plates, such as high strength, excellent toughness and weldability, Controlled rolling and controlled cooling make it possible to satisfy high strength and high toughness requirements which could only be achieved conventionally by off-line heat treatment located close to the mill, to a practical operation type of process continuation also responds to the needs of higher productivity and shorter production time that are always demanded in industrial products[7]. The toughness of the line pipes is paramount in their suitability for application.

The joint resulting from contact welding is quite narrow, with a central $2 \mathrm{~mm}$ wide region, but it represents a source of weakness, so the welding process is immediately followed by induction heat treatment. The intention of the latter is to refine the microstructure by reaustenisation at a lower temperature [8-10].

One of the TMCR are the Alform series i.e.thermo mechanically rolled, wieldable and bendable fine grain structural steels. Plates made of these steels combine the good toughness properties of the thermo-mechanically rolled fine-grain steels according to EN 10025-4 with the excellent cold forming properties of the cold forming steels according to EN 10149-2.The alloying concept provides very low carbon contents and low carbon equivalents, which aims in very good weldability [11]. In particular, the high-strength grades provide special advantages in areas, where weight savings are of great importance. Although the heattreatment improves thetoughness of the welded region, the increase is not as large as might be expected from the reduction in the scale of the microstructure [12-13].

Basing on the previously mentioned facts it is clear that basic idea in this research work is to verify proposed welding technology for production of steel pipe made of micro alloyed steel X60M intended for natural gas transportation using HFCW process trough very complex mechanical, microstructural and technological investigations. metala. Struja koja teče duž ivica trake do vrha "V" klina trake postiže temperaturu zavarivanja. Struja će takođe imati tendenciju da teče oko unutrašnje kružnice]. Ovo zagreva celu cev, i ne doprinosi procesu zavarivanja.

Kontrolisani termo-mehanički proces (TMCP) je jedna od tehnika kontrole mikrostrukture, kombinovanjem kontrolisanog valjanja i kontrolisanog hlađenja, da bi se dobila odlična svojstva čeličnih limova, kao što su visoka čvrstoća, odlična žilavost i zavariljivost. Kontrolisano valjanje i kontrolisano hlađenje omogućavaju da se zadovolje zahtevi visoke čvrstoće i visoke žilavosti što bi se moglo postići samo naknadnom konvencionalnom termičkom obradom u neposrednom nastavku valjanja, kao i praktičan tip rada kontinualnog procesa što odgovara većoj produktivnosti i kraćem vremenu proizvodnje, što se uvek traži kod industrijskih proizvoda [7]. Žilavost cevovoda je najvažnija u njihovoj podobnosti za primenu.

Spoj koji je rezultat kontaktog zavarivanja je dosta uzak, sa centralnom regijom širine $2 \mathrm{~mm}$,ali on predstavlja izvor oslabljenja, tako da je proces zavarivanja praćen indukcionom termičkom obradom. Namera je da se rafiniše mikrostruktura reaustenitizacijom na nižoj temperaturi [8-10].

Jedan od TMCR je Alform serija t.j. termomehanički valjani, zavarljiv i savitljiv finozrni konstrukcijski čelik. Ploče od ovih čelika kombinuju dobre žilavosti finozrnih termo-mehanički valjanih čelika prema EN 10025-4 s dobrim svojstvima za hladno oblikovanje prema EN 10149-2. Koncept legiranja zasnovan je na vrlo niskom sadržaju ugljenika i niskom ugljenikovom ekvivalentu, koji obezbeđuje dobru zavarljivost [11]. Posebno, klase visoko-čvrstih čelika imaju prednosti u područjima gde je smanjenje težine od velikog značaja. lako termička obrada poboljšava žilavost područja zavarivanja, povećanje nije toliko veliko kao što se moglo očekivati smanjenjem skale mikrostrukture [12-13].

Bazirajući se na prethodno navedenim činjenicama, jasna je osnovna ideja u ovom istraživanju, provera predložene tehnologije zavarivanja za proizvodnju čeličnih cevi od mikro-legiranih čelika X60M namenjenih za transport prirodnog gasa, postupkom HFCW, preko vrlo kompleksnih mehaničkih, mikrostrukturnih i tehnoloških ispitivanja. 


\section{Material and experimental} Raw material

Raw material used (steel coils) for production of pipes for natural gas transportation was micro alloyed steel with designation X60MPSL2. Designation of steel is according to API 5, $45^{\text {th }}$ Edition / ISO3183. Explanation of designation is the following: $X$ means steel for pipe production according API. Digits $60 \mathrm{ksi}$ concerns to yield strength of steel i.e. to $420 \mathrm{MPa}$. M means that steel is produced by thermo mechanical rolling process. PSL refers to the product specification level where PSL2 provides a more extensive chemical composition complete with a mandatory minimum. Chemical composition and mechanical properties of raw material are given in the tables $1-3$.

\section{Materijal i eksperiment Materijal sirovine}

Korišćena sirovina (čelična traka namotana) za proizvodnju cevi za transport prirodnog gasa je mikro-legirani čelik oznake X60M PSL2. Označavanje čelika je prema API 5, 45.izdanje / ISO3183. Objašnjenje oznaka je sledeće: $X$ znači čelik za proizvodnju cevi po API. Cifre $60 \mathrm{KSI}$ označavaju napon tečenja čelika t.j. do $420 \mathrm{MPa}$. M znači da se čelik proizvodi termo - mehaničkim postupkom valjanja. PSL se odnosi na nivo specifikacije proizvoda gde PSL2 daje opširniji hemijski sastav zajedno sa obaveznim minimumom. Hemijski sastav i mehanička svojstva sirovog materijala dati su u tabelama 1-3.

\begin{tabular}{|l|l|l|}
\hline $\begin{array}{l}\text { El. } \\
\%\end{array}$ & $\begin{array}{l}\text { Measured } \\
\text { Mereno }\end{array}$ & Standard \\
\hline $\mathrm{C}$ & 0.074 & 0.12 \\
\hline $\mathrm{Si}$ & 0.184 & 0.45 \\
\hline $\mathrm{Mn}$ & 1.17 & 0.16 \\
\hline $\mathrm{P}$ & 0.012 & 0.025 \\
\hline $\mathrm{S}$ & 0.004 & 0.015 \\
\hline $\mathrm{Cu}$ & 0.0233 & \\
\hline $\mathrm{Cr}$ & 0.024 & \\
\hline $\mathrm{N}$ & 0.007 & \\
\hline $\mathrm{V}$ & 0.0403 & \\
\hline $\mathrm{Nb}$ & 0.0357 & \\
\hline $\mathrm{Ti}$ & 0.0111 & \\
\hline
\end{tabular}

Table 1 Chemical composition of the raw material measuredand according API standard requirement Tabela 1 Hemijski sastav materijala sirovine-izmereni i prema zahtevu API standarda

\begin{tabular}{|l|c|c|c|}
\hline \multicolumn{4}{|c|}{ Tensile test } \\
Ispitivanje zatezanjem \\
\hline & $\mathrm{Rp}_{0.2}$ & $\mathrm{Rm}$ & $\mathrm{A} \%$ \\
\hline $\mathrm{BM}$ & 527 & 588 & 32.7 \\
OM & 527 & 584 & - \\
\hline $\begin{array}{l}\text { WM } \\
\text { MS }\end{array}$ & 530 & 584 \\
\hline
\end{tabular}

Table 2 Mechanical properties of the raw material and weldment Tabela 2 Mehaničke osobine materijala sirovine i zavarenog elementa

\begin{tabular}{|l|l|l|l|l|}
\hline & \multicolumn{4}{|c|}{ Charpy V-notch, 0 } \\
\hline & 1 & 2 & 3 & $\mathrm{Av}$ \\
\hline $\begin{array}{l}\text { BM } \\
\text { OM }\end{array}$ & 210 & 208 & 207 & 205 \\
\hline $\begin{array}{l}\text { WM } \\
\text { MŠ }\end{array}$ & 190 & 180 & 165 & 179 \\
\hline $\begin{array}{l}\text { HAZ } \\
\text { ZUT }\end{array}$ & 203 & 200 & 185 & 196 \\
\hline
\end{tabular}

Table 3 Impact toughness of raw material weld metal and HAZ Tabela 3 Vrednosti udarne žilavosti metala šava i ZUT 
Before to start with automatic HFWP preliminary welding technology, based on the technical knowledge and the former experiencewas proposed. The most important welding parameters are given in the table 4 .
Pre nego što će se početi sa automatskim HFWP predložena je preliminarna tehnologija zavarivanja, na osnovu tehničkih znanja i prethodnog iskustva. Najvažniji parametri zavarivanja su dati u tabeli 4.

\begin{tabular}{|l|l|}
\hline $\begin{array}{l}\text { Welding parameters } \\
\text { Parametri zavarivanja }\end{array}$ & $\begin{array}{l}\text { Values } \\
\text { Vrednosti }\end{array}$ \\
\hline $\begin{array}{l}\text { Welding speed (m/min) } \\
\text { Brzina zavarivanja }\end{array}$ & 22 \\
\hline $\begin{array}{l}\text { Voltage }(\mathrm{kV}) \\
\text { Napon }\end{array}$ & 14,3 \\
\hline $\begin{array}{l}\text { Current intensity }(\mathrm{A}) \\
\text { Jačina struje }\end{array}$ & $23-24$ \\
\hline $\begin{array}{l}\text { Current Frequency Hz } \\
\text { Frekvenca struje }\end{array}$ & 400 \\
\hline $\begin{array}{l}\text { Generator power kW } \\
\text { Snaga generatora }\end{array}$ & 600 \\
\hline $\begin{array}{l}\text { Voltage index } \\
\text { Indeks napona }\end{array}$ & $57-58$ \\
\hline
\end{tabular}

Table 4 Typical parameters used for welding of HFRW

Tabela 4 Tipične vrednosti korišćenih parametara za HFRW

Delivered raw material for steel pipe production wasin the form coils. The coils have to be with the proper wildness in order to beobtaining a pipe with necessary diameter The coils are bringingto the starting point in the technological line (Figure 2a) from the store,figure 1a. Uncoiled strip is involved in the technological/production line (Figure 1b) by cranes. Formation of pipes from the strip is attended by the pressure of welding rolls. The rolls are properly chosen in accordance with pipe diameter and thickness of materialFormed pipe by the system of rolls before welding is presented in figure $2 b$. After forming, the pipes were welded implementing electro resistance contact welding with the contactors, figure $1 \mathrm{c}$ and $3 \mathrm{a}$. Starting point of pipe welding and V-wedge are given in figure $4 \mathrm{~b}$. Parameters of the wedge play very important role concerning the quality of the welded joint. After welding, pipes were cut in the length of 12 meters using circular mechanical saw as is presented in figure 1 ( $d$ and $e$ ).

Softened and melted edges of the pipes are connected by the pressure of squeezing rolls (Figure 3). Excesses material and impurities are squeezed out on the inner and outer pipe surface. (Figure 4). Removal of the material (slag) is performed with special knifes located on the inner and outer side of pipe.
Isporučena sirovina za proizvodnju čeličnih cevi je u obliku namotaja. Namotaji moraju biti odgovarajuće širine kako bi se dobijale cevi potrebnih prečnika. Namotaji se donose na polazište u tehnološkoj liniji (slika 2a) iz magacina, slika 1a. Odmotana traka se uvodi u tehnološku/proizvodnu liniju (slika 1b) kranovima. Formiranje cevi iz trake postiže se pritiskom valjaka za zavarivanje. Valjci su odgovarajuće izabrani prema prečniku cevi i debljini materijala.

Oblikovana cev, sistemom valjaka, pre zavarivanja prikazana je na slici 2b. Nakon oblikovanja, cevi su zavarene primenom elektro-otpornog kontaktnog zavarivanja preko kontaktora, slika 1c i 3a. Početna tačka zavarivanja cevi i V-klin su dati na slici $4 b$. Parametri klina igraju vrlo važnu ulogu u pogledu kvaliteta zavarenog spoja.

Nakon zavarivanja, cevi se seku na tačno 12 metara dužine kružnom mehaničkom testerom kao što je prikazano na slici 1 (d i e).

Omekšale i istopljene ivice cevi se spajaju pritiskom valjaka za istiskivanje (Slika 3 ). Višak materijala i nečistoća su istisnuti na unutrašnje i spoljašnje površine cevi. (Slika 4). Uklanjanje materijala (šljake) se obavlja posebnim noževima koji se nalaze na unutrašnjoj i spoljašnjoj strani cevi. 


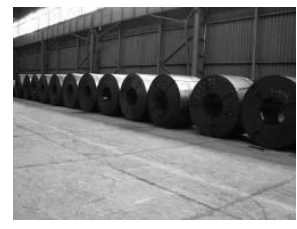

a

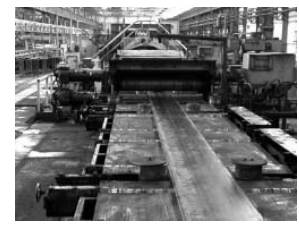

b

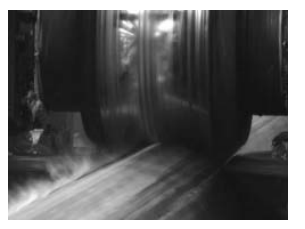

C

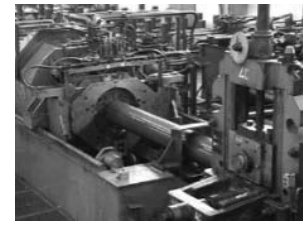

d

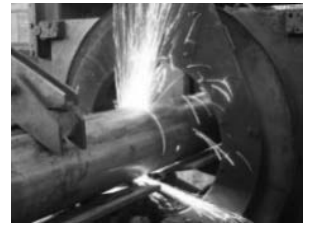

e

Figure 1 (a-d) Production of steel pipe from the raw material API X60 steel

a. Store for raw material $b$. involving raw material in the production line $c$. welding of pipe $d$. welded pipe e. cutting of the pipe to the proper length

Slika 1 (a-d) Proizvodnja čeličnih cevi od sirovine -čelika API X 60

a. Magacin sirovina b. uvođenje sirovine u proizvodnu liniju c. zavarivanje cevi d. zavarena cev e. sečenje cevi na odgovaraju dužinu

As is shown in the figure 5 , welded pipes are additionally subjected to heat treatment (normalization) in order to improve properties of welded joint (relaxation of stresses and microstructure). Normalization is performed at temperature of $900^{\circ} \mathrm{C}$ by six inductors. The width of normalized layer is about $20 \mathrm{~mm}$.
Kao što je prikazano na slici 5 , zavarene cevi se naknadno podvrgavaju termičkoj obradi (normalizacija) kako bi se poboljšala svojstva zavarenog spoja (relaksacija napona i mikrostrukture). Normalizacija se obavlja na temperaturi od $900^{\circ} \mathrm{C}$ sa šest induktora. Širina normalizovanog sloja je oko $20 \mathrm{~mm}$.

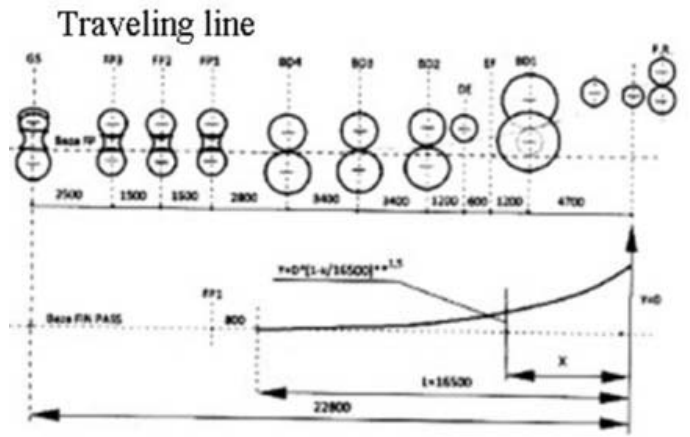

a

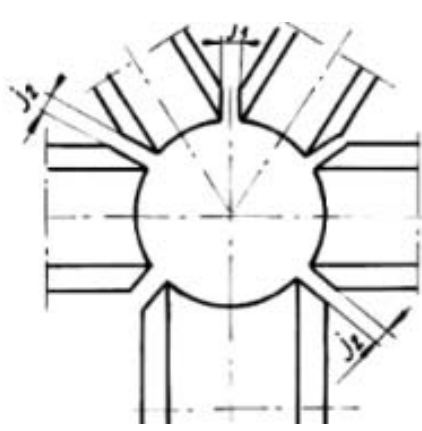

$b$

Figure 2a Technological line for contact welded pipes production $b$. final forming of pipe before welding $b$. formed pipe before HFCW

Slika 2a Tehnološka linija za proizvodnju kontaktno zavarenih cevi b. završno oblikovanje cevi pre zavarivanja $c$. oblikovana cev pre HFCW
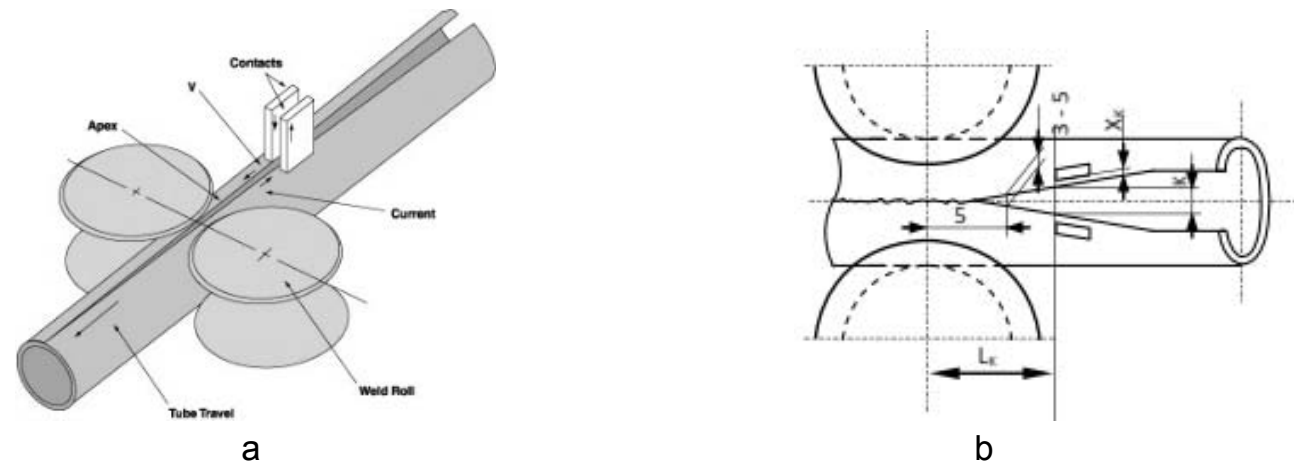

b

Figure 3 Electro resistance contact welding of pipes

a.Contactors $b$. Welding start pointand V-wedge

Slika 3 Elektrootporsko kontaktno zavarivanje cevi a. kontaktori b. početna tačka zavarivanja i V klin 


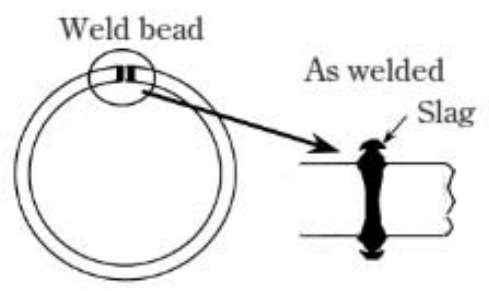

Figure 4 Pipe with excess material (slag)

Slika 4. Cev sa viškom materijala

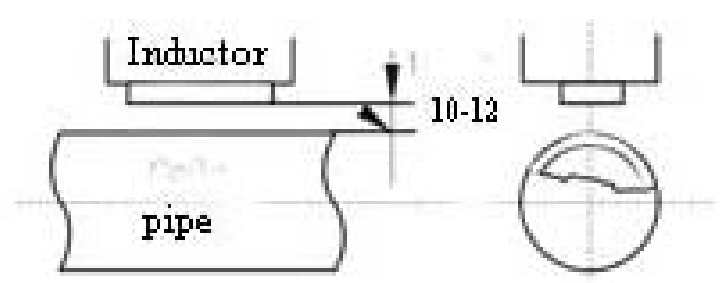

Figure 5 Induction heating of weld with 6 inductors

Slika 5 Indukciono zagrevanje zavarenog spoja sa 6 induktora

\section{Investigation of preliminary welded pipes}

Many complex investigations were performed in order to confirm quality of the welded joints. A welded pipe was subjected to hydrostatic testing under the pressure of 10 bars for period of $10 \mathrm{~s}$. There was no leakage appearing during the testing. For flattening test two segments, $200 \mathrm{~mm}$ wide were cut and tested under pressure. Position of welds during the testing is shown at figure 6 . Pressing of segment last until opposite sides of pipe touch each other.No defects i.e.cracks were detected during testing.

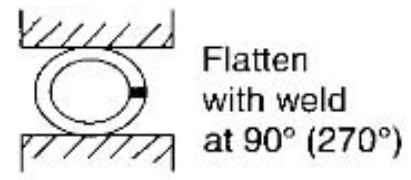

\section{Istraživanje preliminarno zavarenih cevi}

Mnoštvo složenih istraživanja je obavljeno kako bi se potvrdio kvalitet zavarenih spojeva. Zavarena cev je bila podvrgnuta hidrostatičkom ispitivanju pritiskom od 10 bara u periodu od $10 \mathrm{~s}$. Nije bilo nikakvog curenja tokom ispitivanja. Za ispitivanje spljoštavanjem, isečena su dva segmenta, $200 \mathrm{~mm}$ širine i podvrgnuta su pritiskanju.Položaj zavarenog spoja tokom ispitivanja prikazan je na slici 6 . Pritiskanje segmenta traje dok se suprotne strane cevi ne dodirnu. Nikakvi defekti t.j. prsline nisu otkrivene tokom ispitivanja.

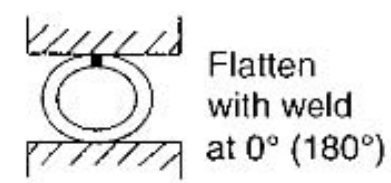

Figure 6 Flattening test of pipe segments

Slika 6 Ispitivanje spljoštavanjem segmenata cevi

Visual inspectionwas performed in order to detect surface defects or geometrical misalignment of the pipes edges. Testing was performed according BS EN ISO 17637:2011, and no defect was detected. From the investigatedpipe were cut specimens for mechanical testing. Transferal tensile testing of welds was performed according EN ISO 4136. Three tensile testing specimens were prepared perpendicular to the welded joint, figure 7 . The result is given in table 2 . In all specimens breaking of specimens was out of the welded joint. Obtained values from testing are almost identical with base metal.
Vizuelna kontrola je obavljena u cilju otkrivanja oštećenja površine ili geometrijske nesaosnosti ivica cevi. Ispitivanje je obavljeno prema BS EN ISO 17637: 2011, a nijedan defekt nije otkriven. Od ispitivanih cevi su isečene epruvete za mehanička ispitivanja. Poprečno ispitvanje zatezanjem zavarenog spoja je izvedeno u skladu sa EN ISO 4136. Tri epruvete za ispitivanje zatezanjem su pripremljene upravno na zavareni spoj, slika 7 . Rezultat je dat u tabeli 2.Na svim epruvetama, prekid epruvete je bio van zavarenog spoja. Dobijene vrednosti pri ispitivanju su gotovo identične sa osnovnim materijalom. 


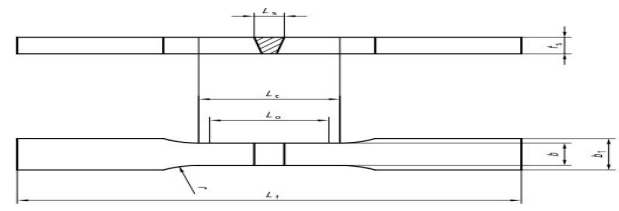

Figure 7 Longitudinal specimen

Slika 7 Podužna epruveta

Bend testing was made according to the EN ISO 5173:2010+A1:2011 standard. Sampling of the bending probes is according to schematic illustration in figure 8 (a-c). Bending angle was $180^{\circ} \mathrm{C}$. Results of testing are given in the table 5 . All tested probes fulfilled standard requirement.

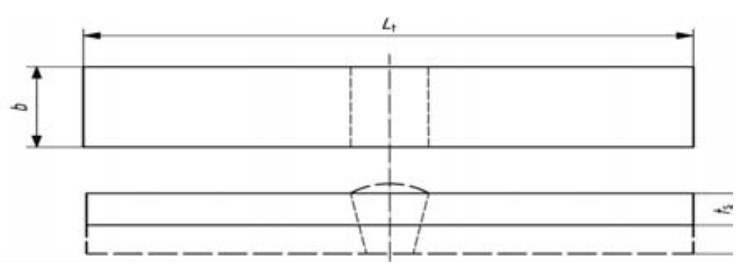

a
Ispitivanje savijanjem je obavljeno u skladu sa EN ISO 5173: 2010 + A1: 2011. Uzorkovanje epruveta za savijanje je u skladu sa shematskom ilustracijom na slici $8(a-c)$. Ugao savijanja je $180^{\circ} \mathrm{C}$. Rezultati ispitivanja su dati u tabeli 5 . Sve ispitane epruvete su ispunile zahteve standarda.

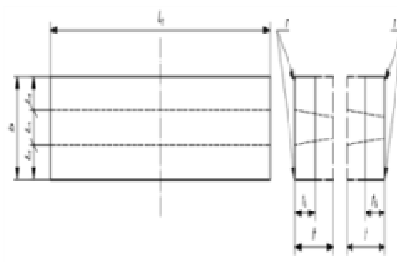

b

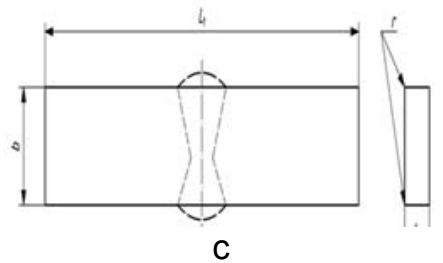

Figure 8 (a-c) a.Transverse root bend test specimen for a butt weld (TRBB) b. Longitudinal bend test specimen for a butt weld (LFBB and LRBB) c.Transverse side bend test specimen for a butt weld (SBB) $L$-length of the specimen $b$-width of specimen, $t$ - thickness of specimen

Slika 8 (a-c) a.Poprečna epruveta za ispitivanje savijanjem korena kod sučeonog spoja (TRBB) b.Podužna epruveta za sučeoni spoj(LFBB i LRBB) c.Poprečna epruveta za bočno savijanje sučeono spoja (SBB)

$L$-dužina epruvete $b$ - širina epruvete $c$. debljina epruvete

\begin{tabular}{|c|c|c|c|c|}
\hline $\begin{array}{c}\text { Nr. } \\
\text { Br. }\end{array}$ & $\begin{array}{c}\text { Type } \\
\text { of test } \\
\text { Tip } \\
\text { testa }\end{array}$ & $\begin{array}{c}\text { Dimension } \\
\text { of } \\
\text { specimen } \\
\text { Dimenzija } \\
\text { epruvete }\end{array}$ & $\begin{array}{c}\text { Bending } \\
\text { angle } \\
\text { Ugao } \\
\text { savijanja }\end{array}$ & $\begin{array}{c}\text { Results } \\
\text { Rezultati }\end{array}$ \\
\hline 1 & TFB & $6.5 \times 30$ & $180^{\circ}$ & good /dobro \\
\hline 2 & TFB & $6.5 \times 30$ & $180^{\circ}$ & good \\
\hline 3 & TFB & $6.5 \times 30$ & $180^{\circ}$ & good \\
\hline 4 & TRB & $6.5 \times 30$ & $180^{\circ}$ & good \\
\hline 5 & TRB & $6.5 \times 30$ & $180^{\circ}$ & good \\
\hline 6 & TRB & $6.5 \times 30$ & $180^{\circ}$ & good \\
\hline 7 & LRB & $6.5 \times 30$ & $180^{\circ}$ & good \\
\hline 8 & LFB & $6.5 \times 30$ & $180^{\circ}$ & good \\
\hline 9 & SB & $6.5 \times 6.5$ & $180^{\circ}$ & good \\
\hline 10 & SB & $6.5 \times 6.5$ & $180^{\circ}$ & good \\
\hline
\end{tabular}

Table 5 Results of bend testing of the welded joint

Tabela 5 Rezultati ispitivanja savijanjem zavarenog spoja

Meaning of the abbreviations is the following:

TFB - transversal face bend, TRB - transversal root bend, LFB - longitudinal face bend, LRB - longitudinal root bend, SB - side bend.

Značenje skraćenica:

TFB- poprečno savijanje lica, TRB- poprečno savijanje korena,LFB- podužno savijanje lica, LRB-podužno savijanje lica, SB-bočno savijanje 
Impact toughness testing was perfumed according EN ISO 9016:2012 and EN ISO 148-1:2010. Besides base metal, weld metal and HAZ were tested too. Results from testing are given in the table 3. Impact testing was done at temperature of $0^{\circ} \mathrm{C}$. It has to be point out that approximation of obtained results was made in this case. The reason is that nonstandard Chapy specimen were used. Such specimens were prepared because the thickness of the pipe was $6,5 \mathrm{~mm}$ and for the standard Charpy specimens should be with thickness of $10 \mathrm{~mm}$. By such reason, Charpy specimens were machined to the thickness of 5 $\mathrm{mm}$ from the bottom side. According standard determination obtained values from testing have to be one half of the values prescribed in standard for the specimen with thickness of $10 \mathrm{~mm}$. Sampling of Charpy specimens for determination of impact toughness in the weldment and HAZ is given in the figure 9.

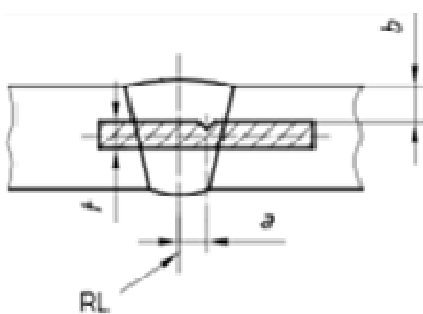

Ispitivanje udarne žilavosti je sprovedeno prema EN ISO 9016:2012 i EN ISO 148-1: 2010. Osim osnovnog materijala, metal šava i ZUT su takođe ispitani. Rezultati ispitivanja su dati u tabeli 3 . Ispitivanje udarom je urađeno na temperaturi od $0^{\circ} \mathrm{C}$. Mora se naglasiti da je napravljena aproksimacija dobijenih rezultata u ovom slučaju. Razlog je to što su se koristile nestandardne epruvete po Šarpiju. Takvi uzorci su pripremljeni, jer je debljina cevi $6,5 \mathrm{~mm}$, a za standardnu Šarpi epruvetu treba da je debljine $10 \mathrm{~mm}$. Iz tog razloga, Šarpi epruvete se mašinski obrađuju na debljinu od $5 \mathrm{~mm}$ sa donje strane. Prema standardnom određivanju, dobijene vrednosti pri ispitivanju moraju biti jedna polovina vrednosti propisanih $u$ standardu za uzorak debljine $10 \mathrm{~mm}$. Uzorkovanje Šarpi epruveta za određivanje udarne žilavosti u zavarenom elementu i ZUT dato je na slici 9.

Figure 9 Sampling of Charpy specimens for determination impact toughness of weld metal and HAZ Slika 9 Uzorkovanje Šarpi epruveta za određivanje udarne žilavosti metala šava i ZUT

Macrostructure of HF welded joint is presented in the figure 10 ( $a$ and $b$ ). From the macro photo can be clearly seen characteristic area in the welded joint. In the middle of the joint is fusion line. From the both sides of fusion line is HAZ and base metal which don't suffer from the welding heat input.
Makrostruktura HF zavarenog spoja prikazana je na slici 10 (a i b). Sa makro fotografija se jasno vidi karakteristično područje zavarenog spoja. U sredini spoja je linija stapanja. Sa obe strane linije stapanja je ZUT i osnovni materijal koji nije pretpeo uticaj toplote usled zavarivanja.

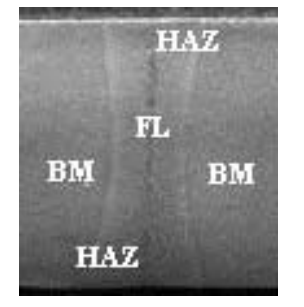

a

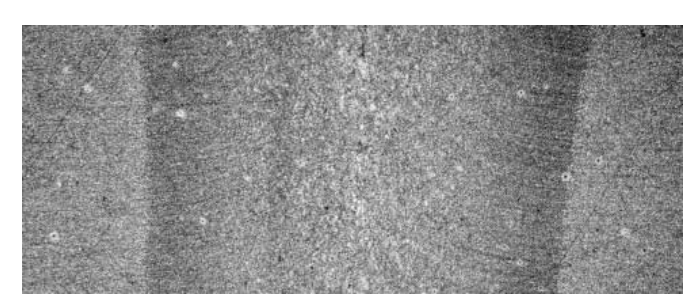

$\mathrm{b}$

Figure 10 ( $a$ and $b$ ) Macro photos of the welded joints Slika 10 (a i b) Makrofotografije zavarenih spojeva

Typical welding defects which can be formed during $\mathrm{HF}$ electric welding like cold laps, entrapped inclusions, cold weld, open weld, cross weld, cracks in the weld porosity in the welding zone are not detected in the welded joint. It can be seen that flux i.e. excess material formed during welding photo is cut (removed) from the upper and lower side of the welded joint.
Tipični defekti zavarivanja koji mogu da nastanu pri VF električnom zavarivanju kao što su hladni nalepci, zarobljeni uključci, hladni zavar, otvoreni zavar, poprečni zavar, prsline u šavu, poroznost u zoni zavarivanja nisu otkriveni u zavarenom spoju. Može se videti da šljaka t.j. višak materijala formiran tokom zavarivanja (fotografija) se reže (uklanja) sa gornje i donje strane zavarenog spoja 


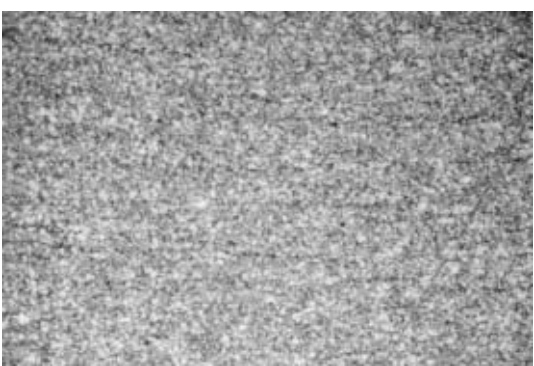

a
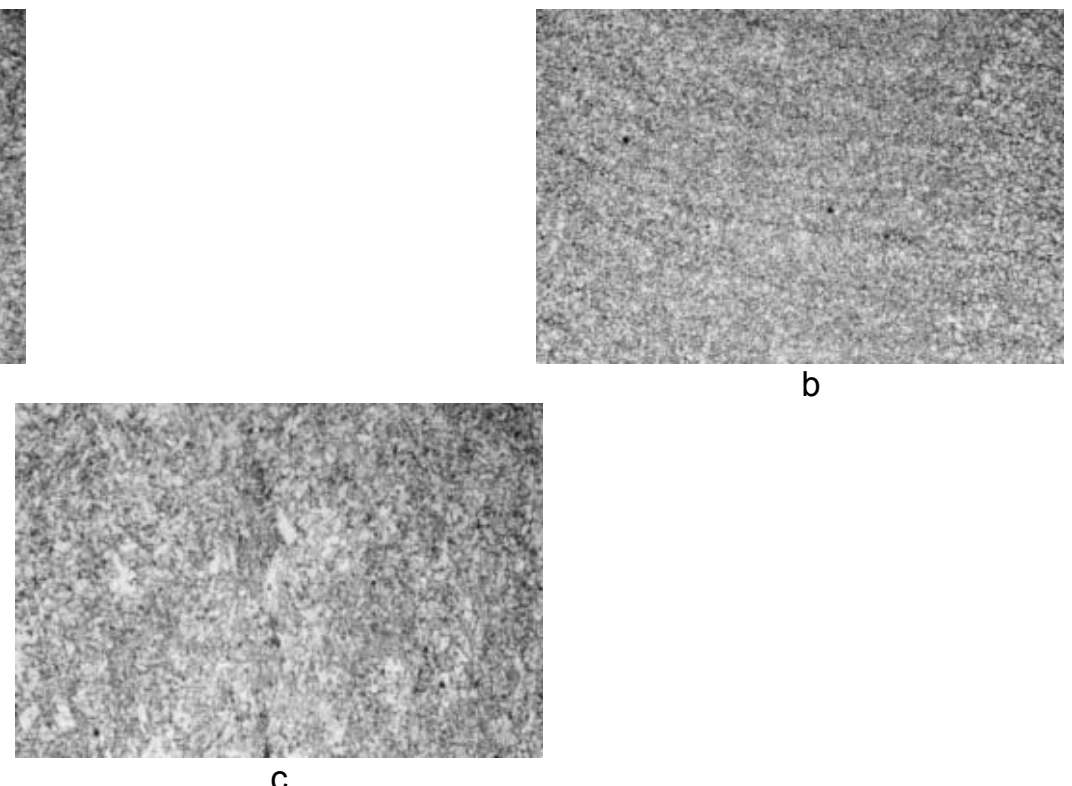

b

Figure 11 (a-c) Microstructure of the welded joint

Slika 11 (a-c) Mikrostruktura zavarenog spoja

Microstructure of the base metal is presented in the figure 11a. It is fine grain ferritic-bainitic microstructure. Fine grain $\mathrm{HAZ}$ zone can be seen in the figure in figure $11 \mathrm{~b}$. Both microstructures are very similar. Deformation of microstructure as result of pressure of forming rolls can be noticed in figure $11 \mathrm{~b}$ too. Fusion line so called ferritic line is given in figure 11c. As can be see microstructure is coarser, and a dominant micro constituent in this area is block ferrite.

On the metallographic specimen was measured hardness measurement according to EN ISO 90151 (figure 10). Measurement was performed across the line parallel with the weld surface. Vickers method (HV10) for hardness measurement was implemented. The highest hardness was noticed in the weld metal and the lowest in the base metal, but generally pretty low hardness values are obtained According expectations, normalization lower the hardness of the welded joint (figure 12).
Mikrostruktura osnovnog materijala prikazana je na slici $11 a$. Ona je finozrna feritno-beinitna. Fino zrna ZUT može se videti na slici na slici $11 \mathrm{~b}$. Obe mikrostrukture su vrlo slične. Deformacije mikrostruktura kao rezultat pritiska valjaka za oblikovanje može se uočiti na slici $11 \mathrm{~b}$. Linija stapanja tzv. feritna linija je data na slici 11c. Kao što se može videti mikrostruktura je grublja, a dominantan mikrokonstituent $u$ ovoj oblasti su blokovi ferita.

$\mathrm{Na}$ metalografskom uzorku je sprovedeno merenje tvrdoće prema EN ISO 9015-1 (slika 10).Merenje je obavljeno po liniji paralelnoj $s$ površinom šava. Primenjena je Vikers metoda (HV10) za merenje tvrdoće. Najveća tvrdoća zabeležena je u metalu šava a najmanja u osnovnom materijalu, ali generalno, dobijene su prilično niske tvrdoće. Prema očekivanjima, normalizacija snižava tvrdoću zavarenog spoja (slika 12).

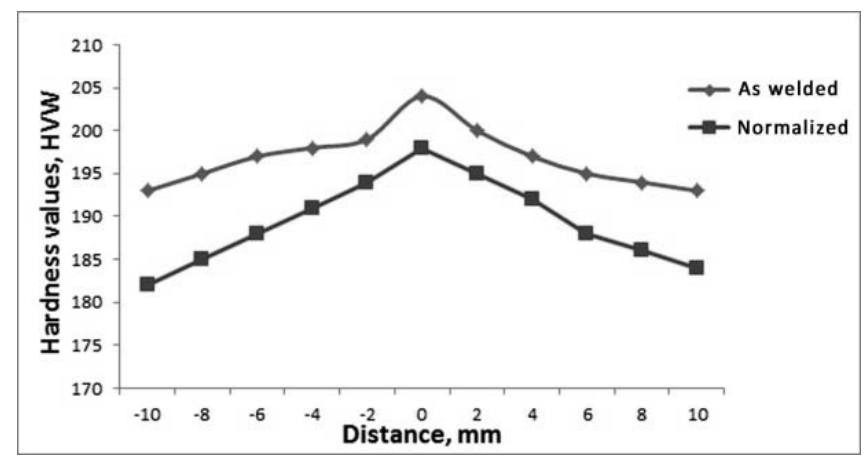

Figure 12 Hardness of the welded joint in the as welded and normalized condition Slika 12 Tvrdoća zavarenog spoja u zavarenom i normalizovanom stanju 


\section{Discussion}

Experimental welding was performed according formerly predicted parameters based on the technical knowledge and former experience. After finishing experimental work in accordance with preliminary given procedure, additional heat treatment (normalization) of welds in width of about $20 \mathrm{~mm}$ was carried to relax stresses in the welded joint. In order to check the properties of pipes very complex mechanical, chemical microstructural and technological investigations were performed mainly according with API 5L standard. Quality of raw material was checked before the welding. It is in accordance with standard requirement. Visual inspection showed that there is nogeometrical defects of the pipe or of surface welding defects. Automatic ultrasonic investigation was done directly in the production line, and didn't detect volumetric welding defects. Hydrostatic test of pipe at pressure of $10 \mathrm{bar} / 10 \mathrm{~s}$ didn't show leakage in the weld or cracks appearing. Flattening test of pipe segment $200 \mathrm{~mm}$ wide didn't reveal any defects in the welded joint after performed test. Hardness measurement showed that max hardness is in the WM something probably because of higher temperature and higher pressure of the welding rolls. Lower hardness was detectedin the HAZ and the base material i.e. TMCR steel. On the contrary measured impact toughness values are quite opposite. So the best values have BM than HAZ and the lowest fusion line. It means that High frequent welding process lower toughness values. Anyhow all toughness values are much higher than standard requirement. Tensile testing of welded joint showed similar results to that of raw material. And all tensile specimens were broken in the base metal. As can be seen from the figure 12 normalization contribute to the lowering of hardness values as result of lowering the stresses in the welded joint.

\section{Conclusion}

This research work is about the identification of the best welding (technological) parameters which can grant the soundnessof pipes realized by high frequency welding HFCW.Performed investigation of preliminarywelded pipes are according API 5L standard. Obtained results of investigation confirmedthat raw material and quality of experimentally produced welded pipe completely satisfy standard requirement. It means that

\section{Diskusija}

Eksperimentalno zavarivanje izvršeno je prema ranije predviđenim parametrima na osnovu tehničkog znanja i iskustva. Nakon završetka eksperimentalnog rada u skladu sa preliminarno datom tehnologijom, sprovedena je naknadna termička obrada (normalizacija) zavarenog spoja širine oko $20 \mathrm{~mm}$ radi otpuštanja napona $\mathrm{u}$ zavarenom spoju. Kako bi proverili svojstva cevi, sprovedena su vrlo kompleksna mehanička, hemijska mikrostrukturna i tehnološka istraživanja u skladu S API 5L standardom. Kvalitet sirovine je proveren pre zavarivanja. To je u skladu sa zahtevima standarda. Vizuelna kontrola je pokazala da ne postoje geometrijski defekti cevi ili oštećenja površine za zavarivanje. Automatsko ultrazvučno ispitivanje je sprovedeno direktno na proizvodnoj liniji, i nisu otkrivene zapreminske greške pri zavarivanju. Hidrostatičko ispitivanje cevi na pritisak od 10 bara / $10 \mathrm{~s}$ nisu pokazali curenja u zavarenom spoju ili pojavu prslina. Ispitivanje spljoštavanjem segmenata cevi širine $200 \mathrm{~mm}$ nije otkrio nikakve nedostatke u zavarenom spoju nakon obavljenog ispitivanja. Merenje tvrdoće je pokazalo da je maksimum tvrdoće u MŠ verovatno zbog viših temperatura i većeg pritiska valjaka za zavarivanje. Manja tvrdoća je otkrivena u ZUT i osnovnom materijalu t.j. TMCR čeliku. Naprotiv tome, izmerene vrednosti žilavosti su sasvim suprotne. Tako, najbolje vrednosti ima OM u odnosu na ZUT a najmanja vrednost je na liniji stapanja. To znači da postupak visokofrekventnog zavarivanja snižava vrednosti žilavosti. U svakom slučaju, sve vrednosti žilavosti su mnogo veće od zahteva standarda. Zatezna ispitivanja zavarenog spoja pokazuju slične rezultate sa onima za materijal sirovine. I sve epruvete za zatezanje su pukle u osnovnom materijalu. Kao što se može videti sa slike 12, normalizacija doprinosi smanjenju vrednosti tvrdoće kao rezultat smanjenja naprezanja u zavarenom spoju.

\section{Zaključak}

Ovaj istraživački rad ima za cilj identifikaciju najboljih zavarivačkih (tehnoloških) parametara koji mogu osigurati ispravnost cevi izrađenih visoko frekventnim zavarivanjem-HFCW. Sprovedena istraživanja preliminarno zavarenih cevi su prema API 5L standardu. Dobijeni rezultati istraživanja potvrdili su da sirovina i kvalitet eksperimentalno proizvodenih zavarenih cevi $u$ potpunosti zadovoljaju zahteve standarda. Ovo znači da je 
preliminary welding procedure become qualified HFCW report for production of X60M pipes. It means that ordered production of pipesfor natural gas transportationcan start.

\section{Literatura}

[1] Santosh KumarS. K. Shukla, S. K. DeAtul Saxena, B. K. Jha, B. Mishra,API X 70 Grade HR Coils for ERW Pipe, International Journal of Metallurgical Engineering 2013, 2(2): 179-187

[2] INOUE Tomohiro, SUZUKI Masahito, OKABE Takatoshi, MATSUI Yutaka, Development of Advanced Electric Resistance Welding (ERW) Linepipe "Mighty Seam TM" with High Quality Weld Seam Suitable for Extra-Low Temperature Services JFE GIHO No. 29 (Feb. 2012), p. 17-21

[3] ENDO Shigeru, NAKATA Naoki, Development of Thermo-Mechanical Control Process (TMCP) and High Performance Steel in JFE, TECHNICAL REPORT No. 20 (Mar. 2015)

[4] VOESTALPINE, Thermomechanically rolled fine-grain steels, Technical terms of delivery for heavy plates

[5] Petru Simion, Vasile Dia,Bogdan Istrate,Corneliu Munteanu, Controlling and Monitoring of Welding Parameters for Micro-alloyed Steel Pipes Produced by High Frequency Electric Welding, Advanced Materials Research Vol. 1036 (2014) pp 464-469

[6] D. KIM, T. KIM, Y. W. PARK, K. SUNG, M. KANG, C. KIM, C. LEE, AND S. RHEE, Estimation of Weld Quality in High-Frequency Electric Resistance Welding with Image Processing, Welding Journal, March 2007, 71s-79s

[7] ARCELOR MITAI, Steel for Oil \& Gas Pipes Line Pipe, OCTG \& Well Intervention prethodni postupak zavarivanja postao izveštaj o kvalifikaciji tehnologije HFCW zavarivanja za proizvodnju cevi od X60M. To znači da poručena proizvodnja cevi za transport prirodnog gasa, može početi.

\section{Literature}

[8] C. Mapelli, C. CornaRESEARCH OF THE BEST TECHNOLOGICAL AND METALLURGICAL PARAMETERS FOR PERFORMING THE ELECTRIC RESISTANCE WELDING OF LOW CARBON STEELS, la metallurgia italiana, ottobre 2008

[9] P. Yan, O. E. G"ung"or, P. Thibaux, M. Liebeherr, H. K. D. H. Bhadeshia, Tackling the Toughness of Steel Pipes Produced by High Frequency Induction Welding and Heat-Treatment, Materials Science and Engineering, A Volume 528, Issues 29-30, 15 November 2011, Pages 84928499

[10] E. Treiss. Induction Annealing of welds in the fabrication of high-frequency induction welded steel line pipes. 3R International, 20(11):627-630, 1981.

[11] J oo, Min Sung, Anisotropy of Charpy Properties in Linepipe Steels, Thesis for Doctor of Philosophy Pohang, Korea, 12 April 2012

[12]John Wright, Optimizing Efficiency inHF Tube Welding Processes TUBE \& PIPE TECHNOLOGY November/December 1999

[13] Athanasios S. Tazedakis, Nikolaos G. Voudouris, Mike Musslewhite MANUFACTURING OF 25MM HEAVY-WALL LINEPIPE USING THE HIGH FREQUENCYINDUCTION (HFI) WELDING TECHNIQUE, A CHALLENGE FOR A PIPE MANUFACTURER, Proceedings of the $8^{\text {th }}$ International Pipeline Conference IPC 2010 September 27-October 1, 2010, Calgary, Alberta, Canada 